The

\title{
Connecticut
}

Agricultural

Experiment

Station,

New Haven

\section{Radicchio Trials}

2002-2003

BY DAVID E. HILL

Bulletin 993

May 2004 


\section{SUMMARY}

In 2002-2003, 10 cultivars of radicchio were grown at Windsor on a sandy terrace soil and at Mt. Carmel on a loamy upland soil. For spring harvest, transplants were set in the field May 23-24 at both sites. For fall harvest, seeds were sown in the field June 14-20 at both sites. In all crops, plants were spaced one foot apart in rows spaced 3 feet apart.

In the spring-transplanted crop, the average head weight at Windsor was $5.3 \mathrm{oz}$, compared to 6.8 $\mathrm{oz}$ at Mt. Carmel. The lower head weight at Windsor was probably due to nutrient depletion by heavy rains in June (6.4 - 9.4 inches). At Windsor, an average of $38 \%$ of plants produced marketable heads, compared to $78 \%$ at Mt. Carmel. Low head weight and percentage of plants producing marketable heads severely limited total estimated yield to $1,840 \mathrm{lb} / \mathrm{A}$ at Windsor. Estimated yield was $4,630 \mathrm{lb} / \mathrm{A}$ at $\mathrm{Mt}$. Carmel. Among all cultivars, Leonardo had the greatest estimated yield at both sites $(4,500 \mathrm{lb} / \mathrm{A}$ and $8,220 \mathrm{lb} / \mathrm{A})$ by virtue of the greatest head weight $(6.2 \mathrm{oz}$ and $9.3 \mathrm{oz})$ and the greatest percentage of plants producing marketable heads $(80 \%$ and $98 \%)$.

In the fall 2002 direct-seeded crop, the average head weight at Windsor was $12.2 \mathrm{oz}$, compared to $10.8 \mathrm{oz}$ at Mt. Carmel. At Windsor, an average of $54 \%$ of plants produced a marketable head, compared to $43 \%$ at Mt. Carmel. At Windsor, the average estimated yield was $6,420 \mathrm{lb} / \mathrm{A}$, compared to 4,180 lb/A at Mt. Carmel. At Windsor, Carmen (7,620 lb/A) and Beacon (7,380 lb/A) had the greatest estimated yields among all cultivars. At Mt. Carmel, Indigo $(6,210 \mathrm{lb} / \mathrm{A})$ had the greatest estimated yield.

In the fall 2003 direct-seeded crop, the average head weight at Windsor was $13.9 \mathrm{oz}$. Head weight of Leonardo and Milan exceeded $16.0 \mathrm{oz}$. An average of $55 \%$ of plants produced marketable heads. Red Preco II (90\%) and Melrose (72\%) produced the most marketable heads. The average estimated yield was 7,799 lb/A. Estimated yields of Red Preco II and Leonardo exceeded 10,000 lb/A.

Days to maturity and harvest span were determined for all cultivars to allow growers to estimate harvest dates for spring and fall crops. Cultivars with short harvest spans can be selected for a single harvest or long harvest spans to maintain supplies of radicchio for roadside stands or farmer's markets. 


\section{RADICCHIO TRIALS, $2002-2003$}

\section{By David E. Hill}

Radicchio (Chicorium intybus) is a red-leafed form of chicory. The greenish-bronze plant has a dense heart of dark-red leaves with creamy-white veins. There are two forms of radicchio. The Chioggia type forms round, dense heads while the Treviso type forms loose, upright heads, similar to romaine lettuce. Both types are highly prized as a salad ingredient or a garnish. It also may be grilled or sautéed with olive oil. Many salad mixes, sold in supermarkets and grocery stores, now contain some radicchio. It adds vibrant color to mixes of head lettuce and romaine. By itself, radicchio is somewhat bitter, but mixed with other salad greens, its tangy taste is muted.

Radicchio was originally grown in the Veneto region of Italy, the source of early imports (Sokolov, 1985). Italian farmers tamed its wild nature by natural selection. Recent developments by geneticists have produced cultivars that are more uniform in growth and maturity. Imports from Europe have been supplemented by domestic production in California, New Jersey, and Florida.

Present outlook. Production in Connecticut has been confined largely to farms whose produce is sold directly to the consumer through roadside stands and farmer's markets.

In 1986 and 1987, I tested a total of 25 cultivars, mostly from Europe, to determine those best suited to Connecticut's soil and climate (Hill 1988). Most of these trials were direct seeded for fall production. Among the 25 cultivars tested, none remain available through catalogue sales. The new cultivars have been bred for uniformity of maturity and head quality. In this bulletin, I report the yield and quality of 10 new cultivars, mostly the heading Chioggia type that are popular in commercial sales.

\section{MATERIALS AND METHODS}

Sites and soils. Trials of radicchio were conducted at the Valley Laboratory, Windsor, on Merrimac sandy loam, a sandy terrace soil with somewhat limited moisture holding capacity and at Lockwood Farm, Mt. Carmel (Hamden), on Cheshire fine sandy loam, a loamy upland soil with moderate moisture holding capacity.

Seeds and varieties. Graded seed of radicchio was obtained from several domestic seed companies. The cultivars included eight dark-red, round Chioggia types, Ambra, Beacon, Carmen, Indigo, Leonardo, Melrose, Milan and Red Preco II, one variegated pink and green
Chioggia type, Tauro, and one red upright Treviso type, Versuvio.

Field management. For all crops in 2002 and 2003, the soils at both sites were fertilized, pre-plant, with 5-10-10 at a rate of $1300 \mathrm{lb} / \mathrm{A}$. Addition of lime to attain a $\mathrm{pH}$ of 6.5 was unnecessary at both sites in both years. For fall crops, the seeds were sown June 14-20 at both sites in 50-foot rows spaced three feet apart. Seedlings, 2-3 inches high, were thinned to a one-foot spacing in each row, a density of 14,520 plants/A. For the spring crop, seeds were sown on April 1 in standard plastic pots measuring 2 $5 / 8 \times 2 \frac{1 / 4}{4} 215 / 16$ inches, joined in packs of 36 . After germination the 36 -pack trays were thinned to one plant/pot. Water-soluble 20-20-20 fertilizer (one tbsp/gal) was added to the seedlings three weeks after germination. Seedlings were moved to a cold frame on May 7 to harden. They were set in the field May 23-24 one foot apart in 50-foot rows spaced three feet apart, a density of 14,520 plants/A.

The herbicide pronamide (KERB 50W) was applied at $3 \mathrm{lb} / \mathrm{A}$ immediately after seeding the fall crops in 2002 and 2003 to control weeds. Weeds in the plots receiving transplants in spring 2003 were controlled by mechanical cultivation.

Mature heads of radicchio were harvested at 1-2week intervals. The loose outer leaves were trimmed; revealing the dense inner head of dark-red leaves forming the marketable head. The trimmed heads were weighed and judged for quality including density, internal sprouting (a symptom of over-maturity), and the presence of tip-burn, and head rot.

Rainfall. Distribution of rainfall at Windsor and Mt. Carmel throughout the growing season (June through October) is shown in Table 1. The inches of rainfall in each column represents the departure from the 30 -year mean monthly rainfall for Hartford (near Windsor) and Mt. Carmel, reported by the National Weather Service. Total rainfall at Windsor during the 2002 and 2003 radicchio growing seasons was 19.4 and 29.5 inches, respectively, compared to a 30-year average of 15.6 inches. At Mt. Carmel, total rainfall for the same period was 21.6 and 30.5 inches, respectively, compared to a 30 year average of 17.1 inches. 
Table 1. Departure of monthly rainfall (inches) from normal during June-October 2002-2003 at Windsor and Mt. Carmel.

\begin{tabular}{lcll}
\multicolumn{4}{c}{ WINDSOR } \\
June & 30-yr. Avg. & 2002 & 2003 \\
July & 3.2 & 1.8 & 3.2 \\
August & 2.6 & 0.3 & 0.2 \\
September & 3.4 & 0.0 & 0.6 \\
October & 3.4 & 0.6 & 7.9 \\
& 3.0 & 1.1 & 2.0 \\
& \multicolumn{3}{c}{} \\
June & MT. CARMEL & \\
July & 30-yr. Avg. & 2002 & 2003 \\
August & 2.5 & 2.3 & 6.9 \\
September & 3.2 & -1.5 & -1.9 \\
October & 3.9 & -0.2 & 2.6 \\
Jul & 4.2 & 1.6 & 3.5 \\
& 3.3 & 2.3 & 2.3
\end{tabular}

In 2002 at Windsor, rainfall during the growing season was 4.8 inches above normal. Most of the excess occurred in June and October. At Mt. Carmel, rainfall during the growing season was 4.5 inches above normal. Similar to Windsor, most of the excess fell in June and October. Although abundant rain fell in most months, deficits occurred in July and August and required two irrigations to maintain normal growth of the crop.

In 2003 at Windsor, rainfall during the growing season was 14.3 inches above normal. Most of the excess occurred in June and September. At Mt. Carmel, rainfall was 13.4 inches above normal. Although July had a deficit of 1.9 inches, growth of the crop was not inhibited because abundant water was stored in the soil from June rains. Irrigation was unnecessary at both sites during the growing season.

\section{RESULTS}

Yields of direct-seeded cultivars - fall 2002. The total yield of radicchio is measured in terms of head weight and percentage of plants producing marketable heads. From these measurements, I estimated the total yield and expressed them in $\mathrm{lb} / \mathrm{A}$ (Table 2). At Windsor, the average head weight of 10 cultivars was $12.2 \mathrm{oz}$. At Mt. Carmel, the average head weight of 9 cultivars was $10.8 \mathrm{oz}$.

At Windsor, among all cultivars, Leonardo had the greatest head weight $(16.2 \mathrm{oz})$ with Tauro also exceeding the average (13.6 oz). At Mt. Carmel, Tauro had the greatest head weight $(12.4 \mathrm{oz})$ with Leonardo also exceeding the average (12.2 oz).

The percentage of sites with marketable heads was determined by two factors. First, poor germination of the seed created gaps in the row. Often the length of the gaps exceeded the desired l-foot plant spacing. Second, at both sites, an average of $15 \%$ of plants in all cultivars failed to develop marketable heads, thus lowering the overall percentage of marketable heads per planting site within each row.

At Windsor, an average of $54 \%$ of growing sites within the row produced marketable heads, compared to $43 \%$ at Mt. Carmel (Table 2). At Windsor, greater than $70 \%$ of growing sites of Beacon and Carmen produced marketable heads. Red Preco II (66\%), Melrose (62\%), and Versuvio $(60 \%)$ were above average. Leonardo $(48 \%)$, and Milan (46\%) produced the fewest marketable heads. At Mt. Carmel, Indigo (60\%) produced the most marketable heads while Leonardo (26\%) produced the fewest.

Based on a plant population of 14,520 plants/A, the estimated total yield (lb/A) was calculated. At Windsor, the average estimated yield was $6,420 \mathrm{lb} / \mathrm{A}$, compared to 4,180 lb/A at Mt. Carmel. The higher average yield at Windsor was largely due to higher percentages of marketable heads than at Mt. Carmel. The estimated yields of Carmen (7,620 lb/A) and Beacon $(7,380 \mathrm{lb} / \mathrm{A})$ were greatest among all cultivars. The estimated yield of Leonardo $(7,080 \mathrm{lb} / \mathrm{A})$ was above average. Although the percentage of sites producing marketable heads was among the lowest $(48 \%)$, the head weights of Leonardo $(16.0 \mathrm{oz})$ were much greater than all other cultivars. The estimated yield of Red Preco II exceeded 7,000 lb/A and was largely due to aboveaverage sites producing marketable heads.

At Mt. Carmel, Indigo had the greatest estimated yield $(6,210 \mathrm{lb} / \mathrm{A})$ by virtue of the greatest percentage of sites producing marketable heads $(60 \%)$. Leonardo $(2,880$ $\mathrm{lb} / \mathrm{A}$ ) had the lowest estimated yield. Although its head weight was greatest among all cultivars $(12.2 \mathrm{oz})$, its production of marketable heads was lowest (26\%).

Yields of direct-seeded cultivars - fall 2003. At Windsor, average head weight among 7 cultivars tested was $13.9 \mathrm{oz}$, almost 2 ounces greater than the average in 2002. The average head weight of Leonardo $(16.3 \mathrm{oz})$ and Milan $(16.0 \mathrm{oz})$ were greatest among all cultivars.

Melrose $(11.3 \mathrm{oz})$ had the smallest average weight. Although Windsor received 6.4 inches of rain in June, the sandy soil permitted rapid drainage. An average of $55 \%$ of planting sites produced marketable heads. Red Preco II produced the greatest percentage of marketable heads (90\%). Marketable heads of Melrose (72\%), Leonardo $(68 \%)$, and Carmen (65\%) were well above average.

At Mt. Carmel, the direct-seeded crop in 2003 was abandoned because excessive rain in June ( 9.4 inches) rotted most of the seed in the loamy Cheshire soil. Less than $5 \%$ of planting sites contained germinated seed.

At Windsor, total estimated yield of 7 cultivars averaged 7,930 lb/A, about $1,500 \mathrm{lb} / \mathrm{A}$ greater than the average yield in 2002. The estimated yiclds of Red Preco $\mathrm{Il}$, and Leonardo exceeded 10,000 lb/A. High yield of Red Preco II was due to the great number of sites producing 
marketable heads (90\%). The high estimated yield of Leonardo was due to the heavy weight of heads even though the number of sites producing marketable heads was $22 \%$ less than Red Preco II. The estimated yields of Milan and Indigo were lowest because only $48 \%$ of planting sites produced marketable heads.

Table 2. Percent marketable heads, weight, and estimated yield of direct-seeded radicchio, fall 2002 and 2003 and transplanted radicchio, spring 2003.

Fall 2002-direct seeded

WINDSOR

Mktble Avg. Est. yield Heads wt. Ib./A

$\begin{array}{llll}\text { Ambra } & 64 & 11.4 & 6,620 \\ \text { Beacon } & 72 & 11.3 & 7,380 \\ \text { Carmen } & 70 & 12.0 & 7,620 \\ \text { Indigo } & 54 & 10.7 & 5,240 \\ \text { Leonardo } & 48 & 16.2 & 7,080 \\ \text { Melrose } & 62 & 11.3 & 6,360 \\ \text { Milan } & 46 & 11.6 & 4,970 \\ \text { Red Preco II } & 66 & 11.7 & 7,010 \\ \text { Tauro } & 50 & 13.6 & 6,170 \\ \text { Versuvio } & 60 & 10.5 & 5,720\end{array}$

Fall 2003-direct seeded

\begin{tabular}{lllc} 
& & \multicolumn{2}{c}{ WINDSOR } \\
& Mktble & Avg. & Est. yield \\
& Heads & wt. & lb./A \\
Beacon & 52 & 13.3 & 6,280 \\
Carmen & 65 & 13.3 & 7,840 \\
Indigo & 48 & 13.8 & 6,010 \\
Leonardo & 68 & 16.3 & 10,060 \\
Melrose & 72 & 11.9 & 7,780 \\
Milan & 48 & 16.0 & 6,970 \\
Red Preco II & 90 & 12.9 & 10,540
\end{tabular}

Spring 2003-transplanted

\section{WINDSOR}

$\begin{array}{lll}\text { Mktble Avg. } & \text { Est. yield } \\ \text { Heads } & \text { wt. } & \text { lb./A }\end{array}$

Beacon 35

Carmen 25

Indigo

Leonardo

42

Melrose

Milan

80

25

Red Preco II

40

18

$$
6.0
$$

1,910

$4.4 \quad 1,000$

$5.4 \quad 2,060$

$6.24,500$

$5.0 \quad 1,130$

5.6

$3.6 \quad 1,310$

\begin{tabular}{lll} 
& \multicolumn{2}{l}{ MT. CARMEL } \\
Mktble & Avg. & Est. yield \\
beads & wt. & lb./A \\
42 & 10.3 & 3,930 \\
48 & 9.5 & 3,790 \\
42 & 11.3 & 4,310 \\
60 & 11.4 & 6,210 \\
26 & 12.2 & 2.880 \\
48 & 9.9 & 4,310 \\
36 & 10.2 & 3,330 \\
48 & 10.0 & 4,360 \\
38 & 12.4 & 4,480 \\
--- & --- & ---
\end{tabular}

MT. CARMEL

Mktble Avg. Est. yield heads wt. lb./A

$\begin{array}{ccc}--- & --- & -- \\ --- & --- & -- \\ -- & --- & -- \\ --- & --- & -- \\ --- & --- & -- \\ -- & --- & -- \\ --- & --- & --\end{array}$

*Estimated yields/A based on head weight $\mathrm{x} 14,520$ plants/A (3'xl'spacing) x \% marketable heads.

Yield of transplanted cultivars - spring 2003. At Windsor, the average head weight among the seven cultivars tested was $5.3 \mathrm{oz}$ compared to $6.8 \mathrm{oz}$ at $\mathrm{Mt}$. Carmel. Low head weight at both sites from springplanted transplants was probably due to nutrient depletion by leaching of pre-plant fertilizer during the heavy rains in June (Table 1) especially in the sandy soil at Windsor. Leonardo at Windsor (6.2 oz) and Mt. Carmel $(9.3 \mathrm{oz})$ produced the heaviest heads. The heads of Beacon weighed $6.0 \mathrm{oz}$ at both sites. At Mt. Carmel, Red Preco II, 
Indigo, Melrose, and Milan produced heads weighing over $7.0 \mathrm{oz}$.

At Windsor, an average of $38 \%$ of planting sites produced marketable heads, compared to $78 \%$ at Mt. Carmel. When planting transplants, all planting sites were fully occupied. Sites that failed to develop marketable heads were occupied by plants with a loose cluster of leaves, often with an elongated central core, a pre-cursor of bolting. Pre-mature bolting was not observed in the crops at both sites.

At Windsor and Mt. Carmel, Leonardo had the greatest percentage of sites producing marketable heads, $80 \%$ and $98 \%$, respectively. At Mt. Carmel, Indigo also produced a high percentage of marketable heads $(92 \%)$.

At Windsor, the average estimated yield of seven cultivars was $1,830 \mathrm{lb} / \mathrm{A}$ compared to $4,630 \mathrm{lb} / \mathrm{A}$ at Mt. Carmel. Low estimated yield at Windsor was due to the low percentage of marketable heads, compounded with low head weight. The higher estimated yield at Mt. Carmel was due to greater numbers of marketable heads. With fully $80 \%$ of planting sites producing marketable heads weighing $6.2 \mathrm{oz}$, Leonardo had the greatest estimated yield $(4,500 \mathrm{lb} / \mathrm{A})$. At Mt. Carmel, Leonardo had the greatest estimated yield $(8,220 \mathrm{lb} / \mathrm{A})$. Fully $98 \%$ of planting sites produced marketable beads weighing 9.3 oz. Red Preco II had the lowest estimated yield at both sites. Most plants produced a loose cluster of leaves that were unmarketable.

\section{MATURITY AND HARVEST}

Knowing the time it takes to produce a mature head of radicchio from seed or transplant, allows the grower to schedule a planting for harvest at a specific time. In Table 3 , the average days to maturity were calculated from the day of seeding in the greenhouse or field, to the day when half of the heads were harvested.

Maturity. In the direct-seeded crop for fall 2002, at Windsor, the average maturity was 97 days, compared to 108 days at Mt. Carmel. Among 10 cultivars at Windsor, the days to maturity varied 20 days. Red Preco II matured in 84 days, while Leonardo and Tauro matured in 104 days. At Mt. Carmel, the days to maturity varied 14 days. Ambra, Carmen, Leonardo, and Red Preco II matured in 103 days while Milan matured in 117 days. Since the maturities reported in catalogues are averages from trials nation-wide it is important to report the response of plants to local conditions, even though these conditions may vary slightly from year to year. The variations in maturity of individual cultivars within each crop were due to selected genetic variations.

In the fall 2003 direct-seeded crop at Windsor, average maturity of the seven cultivars was 92 days. Among all cultivars, Red Preco II matured earliest (80 days). The remaining cultivars matured 14 days later. There appeared to be little variation in maturity for most cultivars. However, harvest at 2 -week intervals probably masked subtle differences in maturity. Once the radicchio plant forms a dense head, it can be held in the field for $2-3$ weeks without compromising its quality. If, however, the head begins to elongate forming a conical top, as the core lengthens, this sign of over-maturity lessens the value of the head.

In the spring 2003 transplanted crop at Windsor, the average maturity of seven cultivars was 120 days, compared to 109 days at Mt. Carmel. The greater number of days to maturity in a transplanted crop, compared to all direct-seeded crops for fall harvest is attributed to transplanting shock that developed during a period of excessive rain and cool temperatures. About two weeks passed before the transplants began to put on new growth.

At Windsor, Milan and Red Preco II matured in 107 days, more than three weeks earlier than Beacon, Melrose, and Milan (130 days). At Mt. Carmel, Beacon and Melrose matured in 102 days or 10 days before all other cultivars.

Harvest span. Another important facet of maturity is its harvest span, which I define as the number of days to harvest $95 \%$ of the crop. Single heads that matured very early or very late in comparison to the whole population within a single cultivar were excluded. Short harvest spans favor single harvests, by hand, for wholesale contracts. Longer harvest spans require multiple pickings by hand and are desirable for sales through roadside stands and farmer's markets.

In general, harvest spans were shorter in spring than in fall at both sites (Table 3). Harvest spans in spring were seldom more than 10 days while those in fall were 2-6 weeks long. Although the number of days to maturity in spring crops was longer than in fall, the dense head formed in a relatively short time during the heat of late July and early August. In fall, heads developed more slowly as day-length and temperature decrease.

In fall, all cultivars required two or three harvests to gather all marketable heads. In the spring 2003 transplanted crop, single harvests of Indigo, Beacon, and Red Preco II at Mt. Carmel, and Leonardo at Windsor yielded more than $70 \%$ of the marketable crop. In the fall 2003 , direct seeded crop at Windsor, $65 \%$ of Melrose was harvested in a single picking. 
Table 3. Average maturity and harvest span of radicchio cultivars at Windsor and Mt. Carmel, spring and fall, 2002-2003. Numbers in parentheses beside cultivar name are catalogue maturities of direct-seeded radicchio.

Fall 2002 (Harvested September 16-October 30)

WINDSOR
Maturity
days

Span of
harvest
days

$\begin{array}{lll}\text { Ambra (90) } & 98 & 27 \\ \text { Beacon (70) } & 98 & 27 \\ \text { Carmen (75) } & 98 & 27 \\ \text { Indigo (86) } & 98 & 27 \\ \text { Leonardo (81) } & 104 & 20 \\ \text { Melrose (85) } & 98 & 37 \\ \text { Milan (90) } & 98 & 37 \\ \text { Red Preco II (81) } & 84 & 20 \\ \text { Tauro (90) } & 104 & 13 \\ \text { Versuvio (85) } & 91 & 13\end{array}$

\begin{tabular}{ll}
\multicolumn{2}{c}{ MT. CARMEL } \\
$\begin{array}{ll}\text { Maturity } \\
\text { days }\end{array}$ & $\begin{array}{l}\text { Span of } \\
\text { harvest } \\
\text { days }\end{array}$ \\
103 & 27 \\
110 & 35 \\
103 & 35 \\
110 & 20 \\
103 & 13 \\
110 & 16 \\
117 & 30 \\
103 & 20 \\
110 & 16 \\
--- & ---
\end{tabular}

Fall 2003 (Harvested October 2-November 11)

\begin{tabular}{|c|c|c|c|c|}
\hline & $\begin{array}{l}\text { Maturity } \\
\text { days }\end{array}$ & $\begin{array}{l}\text { Span of } \\
\text { harvest } \\
\text { days }\end{array}$ & $\begin{array}{l}\text { Maturity } \\
\text { days }\end{array}$ & $\begin{array}{l}\text { Span of } \\
\text { harvest } \\
\text { days }\end{array}$ \\
\hline Beacon & 94 & 47 & -.- & -.. \\
\hline Carmen & 94 & 47 & --- & $-\cdots$ \\
\hline Indigo & 94 & 47 & --- & -.- \\
\hline Leonardo & 94 & 47 & --- & -.- \\
\hline Melrose & 94 & 47 & -.. & --- \\
\hline Milan & 94 & 47 & --- & $-\cdots$ \\
\hline Red Preco II & 80 & 47 & --- & --- \\
\hline \multicolumn{5}{|c|}{ Spring 2003 (Harvested July 11-August 8) } \\
\hline & $\begin{array}{l}\text { Maturity } \\
\text { days }\end{array}$ & $\begin{array}{l}\text { Span of } \\
\text { harvest } \\
\text { days }\end{array}$ & $\begin{array}{l}\text { Maturity } \\
\text { days }\end{array}$ & $\begin{array}{l}\text { Span of } \\
\text { harvest } \\
\text { days }\end{array}$ \\
\hline Beacon & 130 & 10 & 102 & 10 \\
\hline Carmen & 119 & 23 & 112 & 10 \\
\hline Indigo & 119 & 10 & 112 & 10 \\
\hline Leonardo & 130 & 10 & 112 & 10 \\
\hline Melrose & 130 & 10 & 102 & 10 \\
\hline Milan & 107 & 13 & 112 & 10 \\
\hline Red Preco II & 107 & 23 & 112 & 10 \\
\hline
\end{tabular}

\section{MANAGEMENT}

Selection of cultivars. The 2002 and 2003 trials demonstrated that several cultivars of radicchio, released since 1987, have desirable yield and quality that may be profitable for commercial production and enjoyment by home gardeners in Connecticut. These new cultivars have been bred for uniformity.

For spring plantings using transplants, the choices are few. Leonardo had the greatest yields at both sites with $80-98 \%$ of plants producing marketable heads. Although the days to maturity were longest among all cultivars, the quality of its compact heads was excellent.

Indigo, Melrose, and Milan also produced satisfactory yieids of compact heads. Their sizes were smaller than Leonardo. These four cultivars were satisfactory for multiple harvests, but their harvest span lasted only 10 days. The harvest span for Carmen and Red Preco II lasted three weeks, but their total yields were lower than average.

For direct-seeded plantings for fall harvest, Leonardo, Red Preco II, and Carmen had the greatest yields. The heads of Leonardo were larger than the other cultivars, often exceeding one pound. The total yields of Carmen and Red Preco II were high because the percentage of plants producing marketable heads was 
above average. Cultivars most suitable for multiple harvests were Beacon, Carmen, Melrose, and Milan. Their harvest spans lasted 4-5 weeks. The cultivar most suitable for a single harvest was Red Preco II. Although its harvest span lasted three weeks, fully $70 \%$ of the marketable heads were picked in a single day.

Planting dates. For spring plantings, the use of transplants may be the only option. Transplanting in midto-late May assures a harvest in mid-to-late July. Direct seeding of a spring crop may result in a poor yield of marketable heads. Similar to Belgian endive, another chicory, direct seeding of radicchio in May, when the soil is too cool, may cause the plants to bolt, thus rendering them unmarketable (Hill 1987). If direct seeding is delayed until early June, the crop will mature in August when high temperatures and long days promote rank growth instead of compact heads.

\section{REFERENCES}

Anon. 2001. Commercial production of radicchio. Info. Bull. Johnny's Selected Seeds. Winslow, ME 2 p.

Hill, D.E. 1987. Witloof chicory (Belgian endive) trials 1985. Bull. 843. Conn. Agr. Exp. Sta., New Haven. 8 p.

Hill, D.E. 1988. The chicories: witloof (Belgian endive) and radicchio trials - 1986-1987. Bull. 859. Conn. Agr. Exp. Sta., New Haven. 12 p.

Maynard, D.N., and Hochmuth, G.J. 1997. Knott's handbook for vegetable growers $4^{\text {th }}$ Ed. John Wiley and Sons, New York. 582 p.

Sokolov, R. 1985 The redheaded newcomer. Natural History 7/85: 35-37.
For fall harvests, direct seeding is simple and inexpensive. Direct seeding in mid-June through early July allows sufficient time for the crop to mature in midSeptember through October. Warm days and cool nights favor the formation of compact heads (Anon. 2001). Early frosts in October may wither the outermost leaves that protect the head, but these leaves are usually removed during harvest. Cold temperatures, even in the midtwenties, seldom affect the dense hearts.

Post-harvest management. Under proper storage conditions, radicchio has a fairly long shelf life. After harvest, it can be stored for 2-3 months at a temperature of $31-32^{\circ} \mathrm{F}$ and $90 \%$ relative humidity (Maynard and Hochmuth 1997). If long-term storage is anticipated, the heads should not be severely trimmed. Final trimming should be done just prior to sales. 
Digitized by the Internet Archive in 2011 with funding from

LYRASIS members and Sloan Foundation 

The Connecticut Agricultural Experiment Station (CAES) prohibits discrimination in all its programs and activities on the basis of race, color, ancestry, national origin, sex, religious creed, age, political beliefs, sexual orientation, criminal conviction record, genetic information, learning disability, present or past history of mental disorder, mental retardation or physical disability including but not limited to blindness, or marital or family status. To file a complaint of discrimination, write Director, The Connecticut Agricultural Experiment Station, P.O. Box 1106, New Haven, CT 06504, or call (203) 974-8440. CAES is an equal opportunity provider and employer. Persons with disabilities who require alternate means of communication of program information should contact the Chief of Services at (203) 974-8442 (voice); (203) 974-8502 (FAX); or Michael.Last@po.state.ct.us (E-mail). 
t $\Psi$ t University of Connecticut Libraries 
